\title{
24 THE EFFECTIVENESS OF POLLUTANT REMOVAL FROM MUNICIPAL WASTEWATER IN VERTICAL FLOW CONSTRUCTED WETLANDS
}

\author{
Piotr J. Kowalik ${ }^{1}$, Michal Mierzejewski ${ }^{2}$, Peter F. Randerson ${ }^{3}$, \\ Haydn Gregg Williams \\ 1. 2 - Polytechnical University of Gdansk, Dep. of Sonitary Engineering, 80-952 \\ Gdansk, Poland; \\ 3.4 - Cardiff University, School of Biosciences, CF10 3TL Cardiff, Wales, U.K.
}

\begin{abstract}
The efficiency of pollution removal from municipal sewage in two vertical flow constructed wetlands consisting of gravel filters with surface area $4 \times 5 \mathrm{~m}$, depth $60 \mathrm{~cm}$, covered by reed was evaluated over a period of two years. The flow of wastewater was about $50 \mathrm{~mm}$ per day. Wastewater underwent only mechanical treatment before reed bed B, but reed bed A was supplied with wastewater after biological treatment with activated sludge. Sewage was sampled before and after filtration every 10 days. Measurements were made of sewage supply and discharge, precipitation and wastewater temperatures. The main indicator of efficiency was the elimination of suspended solids, carbon, nitrogen and phosphorus from the wastewater during filtration. The elimination of the pollution load was $2-25 \mathrm{~g}$ per square meter per day for the $\mathrm{BOD}_{5}$ and $0-3.5 \mathrm{~g}$ per square meter per day for total nitrogen. Rates of pollution removal were between 2 and 4 times as high in bed $\mathrm{B}$ as in bed $\mathrm{A}$. The rate of BODs removal and the coefficient $\mathrm{k}$ for $\mathrm{BOD}_{5}$ were strongly dependent on temperature for reed bed $\mathrm{B}$; less so far for bed A. The difference between summer and winter indicates that the surface area of constructed wetland $B$ should be 3 times bigger during winter to obtain the summer rate of $\mathrm{BOD}_{5}$ pollution removal in the climatic conditions of North Poland (54a N).
\end{abstract}

\section{KEYWORDS}

Constructed wetland, Municipal wastewater, Nitrogen, Phragmites australis, Phosphorus, Sewage, Suspended solids, Wastewater treatment.

\section{INTRODUCTION}

Wetlands have been described as ecotones between terrestrial and aquatic ecosystems. They create a transitional environment of high biodiversity with species representing both aquatic and terrestrial environments. Wetlands have the capability of improving water quality by reducing organic loading, i.e. Biological Oxygen Demand (BOD), Nitrogen, Phosphorus, 
Suspended Solids (SS) and immobilising trace metals and other environmental contaminants. Both natural and constructed wetlands have been adopted in the treatment of wastewater.

Constructed wetlands are designed man-made complexes of saturated matrix, emergent, submergent or floating vegetation, associated macroinvertebrate and microbial communities, and water, for the treatment of wastewater (Brix, 1987; Brix, 1993; Kowalik et al, 1995). The advantage of using constructed wetlands is that they provide an environment, which can be monitored more easily than a natural environment.

Simple construction, large buffering capacity, little excess sludge production, simple operation and maintenance costs are the most appealing advantages of these versatile systems. Constructed wetlands may be integrated with existing features of the landscape and with appropriate long-term land use (Mitchell et al, 1995). However their performance is also variable, partly because they are influenced by weather conditions and partly because many of their biological, physical and chemical processes are insufficiently understood to determine design criteria and operating procedures. Nevertheless constructed wetlands can make an important contribution to ensure water supplies of good quality for the health of the environment and for use for human activities.

This paper aims to evaluate the efficiency of the process of pollution removal from municipal sewage in a constructed wetland. The problem of nutrient removal via biomass production and export (Kowalik and Randerson, 1995), and the treatment of sanitary landfill leachate in constructed wetlands were presented separately (Kowalik et al, 1996) and are not discussed here.

Constructed wetlands may be divided into two groups: horizontal subsurface flow systems (HF) or vertical subsurface flow systems (VF). Operators and designers were disappointed in the ability of the early HF systems to oxidise ammonium nitrogen to nitrate. This is clearly related to the limited ability of macrophytes such as reeds to transfer oxygen into soil (Belfiore, 1997). Most HF systems have very low dissolved oxygen content in the effluent. Under these circumstances there will be no oxygen available to oxidise ammoniac nitrogen to nitrate. Vertical flow systems (VF), which combine both surface flow and subsurface flow methods, were developed as an alternative design, which could oxidise ammonia (Felde and Kunst, 1996). The wetland system is flooded on the surface with the treatment water, which is allowed to flow vertically through a soil or sand substrate and discharge via a drain. The bed is usually allowed to dry between applications of irrigated wastewater to promote diffusion of oxygen into it. The bed is bounded by an impermeable layer preventing leaching into the surrounding environment.

VF systems have not been utilised extensively until now because they require more careful construction and selection of fill material compared to other constructed wetland systems (Heritage et al., 1995). A design consisting of several beds laid out in parallel with percolating flow and intermittent loading will increase soil oxygenation several-fold compared to horizontal subsurface flow systems, stimulating sequential nitrification/denitrification and phosphorus adsorption (Brix, 1993).

The role of plants in constructed wetlands is not very clear. The roots, shoots and litter from the plants, along with the soil or other fill material used, support the biofilm, aerobic bacteria and associated organisms and fungi which are the functional components of the system (Hiley, 1995). Rooted emergent aquatic macrophytes, usually Phragmites australis (common reed), are the predominant life form in wetlands covering a significant fraction of the surface, These wetland plants grow naturally in flooded soils in deltas, the edges of rivers and many form rafts that extend into deeper water from the margins. They have the important ability of consolidating sediments and keeping their roots aerated in flooded anaerobic soils. These 
plants naturally colonise areas which are being used for sewage treatment. It is the ability of wetland plants to maintain oxygen supply to their roots, to create a locally aerobic environment, and to deal with the products of anaerobic root respiration that enables them to survive in anoxic/anaerobic sediments (Hiley, 1995). These plants are adapted to growing in highly organic, anaerobic sediments and for this reason can tolerate sudden large loads of effluent with such characteristics (Mitchell et al, 1995).

The main objectives of the research were to undertake systematic monitoring of the long term function of vertical flow constructed wetlands and to obtain numerical values of operating efficiency with a view to improving future design and management of such systems and to create the reliability and predictability of constructed wetlands.

\section{CONSTRUCTION OF TWO EXPERIMENTAL WETLANDS}

The experimental constructed wetlands were located on the site of the ZASPA wastewater treatment plant (WWTP) in Gdansk (Poland). The conventional WWTP was constructed in 1932 according to the design of K. Imhoff and is based on mechanical and biological treatment for municipal wastewater for about 100,000 people.

The pilot scale reed bed consists of two vertical flow beds, (soil filters A and B), both of 20 $\mathrm{m}^{2}$ containing emergent vegetation (Phragmites australis) growing in $0.6 \mathrm{~m}$ deep gravel and sand fill material.

The beds were constructed in a rectangular shape $4 \times 5 \mathrm{~m}$ and depth $60 \mathrm{~cm}$. The surface was flat to allow uniform distribution of the added wastewater. The two beds were made using four layers of mineral material. The surface layer (depth $10 \mathrm{~cm}$ ), intended as a support for vegetation was constructed from sand grains $0.1-2 \mathrm{~mm}$ in diameter. Beneath this was a $20 \mathrm{~cm}$ depth layer of gravel of 2-8 $\mathrm{mm}$ diameter followed by a $15 \mathrm{~cm}$ depth gravel layer with diameter of 8-16 mm. The basal layer was a drainage bed $15 \mathrm{~cm}$ in depth comprising gravel and stones of $16-63 \mathrm{~mm}$ in diameter. Each reed bed was equipped for wastewater supply with a system of pumps, pressure pipes and distribution system at the sand surface. After draining through the bed, treated wastewater was collected in subsurface containers and pumped from these containers back to the wastewater treatment plant installation (Fig. 1). After draining, a proportion of the wastewater remains as capillary water in the bed, accounting to about 0.10 of total volume of the bed. A similar value was measured in column experiments by Kowalik et al. (1979) and Kowalik \& Obarska-Pempkowiak (1985). The pore-space retention time was determined from the active volume of the reed bed occupied by bio-film in capillary water and from the flow rate (see Appendix; Eqn. 1). 


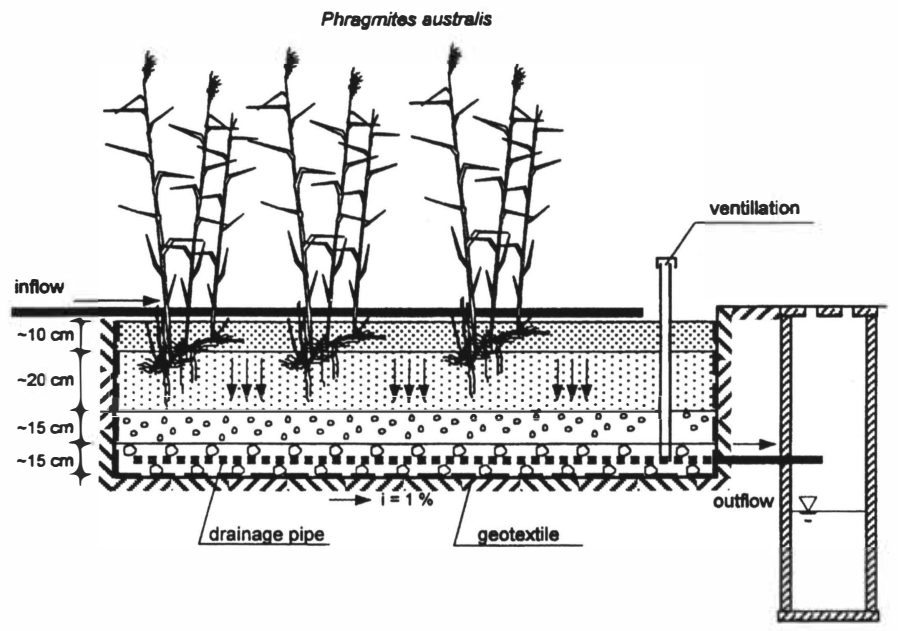

Figure 1. Construction of the vertical reed bed

The vertical walls of the beds were made of timber. The bottom and sides were covered by a geotextile plastic sheet $1.5 \mathrm{~mm}$ thick to avoid any lateral flow or loss of wastewater into the surrounding soil. A system of drainage pipes at the bottom of the bed on the surface of the plastic sheet collects treated wastewater. These pipes were also connected with vertical pipes ending above the bed to allow ventilation of the lower gravel layers. The total mass of each bed was over 40 tonnes of selected coarse sand, fine gravel and coarse gravel with stones. The surface of the bed was vegetated by reeds (Phragmites australis), planted as rhizome cuttings. The supply of wastewater to these beds was taken from the treatment line of the main WWTP and, after passing by a combination of gravity and pump to the beds, returned to the plant. Reed bed A was supplied with wastewater from the secondary settler after biological treatment in an activated sludge aeration tank. Reed bed B was supplied with raw sewage, which had undergone only a primary treatment for the removal of larger particles and suspended solids.

Inflow and outflow of wastewater was under automatic control, designed for the two beds separately, and included several security devices, protecting the system against possible failures. Two pumps bringing wastewater into the reed beds were connected with multifunctional control panels not only to switch the pumps on and off, but to monitor the duration of work of each pump and power supply. Because the capacity of each pump was constant, the duration of work was proportional to the amount of wastewater supplied, which was monitored by a flow meter. The pumps removing wastewater after treatment were under automatic control of float switches in the drainage containers (Mierzejewski, 1999).

After irrigation the beds drain freely, allowing air to refill the bed. The next dose traps the air and this, together with the aeration caused by the rapid dosing onto the beds, leads to good oxygen transfer and hence the ability to nitrify.

\section{MATERIALS AND METHODS RELATED TO WASTEWATER MEASUREMENT}

Wastewater was irrigated into the reed beds in pulses 3 times per day (every 8 hours). The hydraulic loading rate was taken to be $16.7 \mathrm{~mm}$ every 8 hours, giving a daily intensity of 
irrigation equal to $50 \mathrm{~mm} \mathrm{~d}^{-1}, 1 \mathrm{~m}^{3}$ per day in each bed. Despite the constant hydraulic load it was noted that the concentration of different pollutants in the wastewater was changing greatly overttime.

Based on $\mathrm{BOD}_{5}$ of the wastewater entering reed bed $\mathrm{A}$ (after mechanical and biological treatment), the pollution loading rates R (see Appendix; Eqn. 17) were found to vary from 2.5 $\mathrm{g} \mathrm{m}^{-2} \mathrm{~d}^{-1}$ to $15 \mathrm{~g} \mathrm{~m}^{-2} \mathrm{~d}^{-1}$. For a bed with a surface area of $20 \mathrm{mt}^{2}$, these were loads that would originate from 0.7 to 5 Person Equivalents (PE). For reed bed B (irrigated by the wastewater after mechanical treatment in the settler), the load rates were between 6.3 and $26.5 \mathrm{~g} \mathrm{~m}^{-2} \mathrm{~d}^{-1}$, equivalent to 2.1 to $8.8 \mathrm{PE}$. Hence the loads of reed bed B were substantially higher than those of reed bed $\mathrm{A}$.

Monitoring was started in November 1996 after an initial period of one year following propagation of reed and preparation of the beds, and continued until August 1998. Wastewater samples were taken from the settlers of the wastewater treatment plant in the vicinity of the inlets to the pipes connected to the supply pumps, just before the pump started to work. Wastewater samples after treatment was taken from the collecting containers about 15 minutes after the beginning of irrigation. Automatic sampling was performed every 10 days for a period of 2 years. As the irrigation occurred 3 times a day, sampling coincided with only one of 30 pulses of irrigation. It is important to stress that beds were equipped with both inlet and outlet flow meters to determine a balance of water entering and emerging. Average rates of precipitation at the site (measured as about $600 \mathrm{~mm}$ per year) and evapotranspiration (determined by difference) were much lower than the $50 \mathrm{~mm} \mathrm{~d}^{-1}$ of irrigation. The soil temperature of the reed beds at $0.00,0.15$ and $0.60 \mathrm{~m}$ depth was measured on each sampling occasion. Temperature of the waste water (input and output) was measured and the values of outflow temperatures were used to relate to performance of the bed. Air temperature at the level of $2 \mathrm{~m}$ above the ground varied between $-8 \mathrm{PC}$ and $+2 \mathrm{PC}$ during winter, but a depth of $15 \mathrm{~cm}$ the soil temperature remained at approximately $+1^{\circ} \mathrm{C}$, and at a depth of $60 \mathrm{~cm}$ the temperature was $+2 \mathfrak{l} \mathrm{C}$.

Water chemistry analysis was carried out in the laboratory of the Polytechnical University of Gdansk. The following parameters were monitored separately for reed beds $\mathrm{A}$ and $\mathrm{B}: \mathrm{BOD}_{5}$; Suspended solids; Ammonia $\left(\mathrm{NH}_{4}^{+}\right)$; Nitrite $\left(\mathrm{NO}_{2}{ }^{-}\right)$; Nitrate $\left(\mathrm{NO}_{3}{ }^{-}\right)$; Organic nitrogen; Kjeldahl nitrogen (sum of organic and ammonia nitrogen), total nitrogen (sum of Kjeldahl nitrogen, nitrite and nitrate nitrogen), total phosphorus; and Orthophosphate $\left(\mathrm{PO}_{4}{ }^{3-}\right)$. Samples of wastewater were measured according to Polish Standards, which are similar to international regulations.

\section{EESULTS ON POLLUTION AND NUTRIENT REMOVAL RATES}

Concentrations of $\mathrm{BOD}_{5}$, ammonia nitrogen $\left(\mathrm{NH}_{4}{ }^{+}\right)$and total nitrogen $(\mathrm{N})$ in the influent and effluent of the wetlands are shown in Figs. 2-3, 5-6 and 7-8.

Suspended solids were eliminated very efficiently in both reed beds. The concentration of suspended solids in the wastewater after mechanical treatment entering bed B ranged from 64 to $577 \mathrm{mg} \mathrm{dm}^{-3}$. Despite the variability in the raw wastewater, the efficiency of elimination of suspended solids $\eta$ (see Appendix; Eqn. 20) ranged from 63.9 to $94.3 \%$ with a mean value of $79.3 \%$. The concentration of suspended solids in wastewater supplied after mechanical and biological treatment, entering reed bed A, ranged from 12 to $125 \mathrm{mg} \mathrm{dm}^{-3}$ and the efficiency of suspended solids removal ranged from 28.5 to $94.8 \%$, the mean value being $76.6 \%$.

The systems were able to cope with large fluctuations in inflow $\mathrm{BOD}_{5}$ levels. Despite a great variability of input values, relatively stable values of efficiency over time were recorded. In 
reed bed $B$ the wastewater after mechanical treatment contains between 125 and $530 \mathrm{mg} \mathrm{dm}^{-3}$ $\mathrm{BOD}_{5}$ (see Figs. 2 and 3), but the efficiency was relatively stable, between 66.8 and $99.5 \%$, with a mean value of $89.1 \%$.

In reed bed $\mathrm{A}$, irrigated by wastewater after mechanical and biological treatment, the input values of $\mathrm{BOD}_{5}$ of wastewater were between 43.0 and $308.8 \mathrm{mg} \mathrm{dm}{ }^{-3}$. Even with such variability, efficiencies of $\mathrm{BOD}_{5}$ removal of 87.2 to $99.3 \%$ occurred, with a mean value 93.8\%. Coefficient $\mathrm{k}$ for $\mathrm{BOD}_{5}$ removal (see Appendix; Eqn. 12) was calculated and is depicted in Fig. 4 as a function of temperature $T$. The results of monitoring during establishment phase of the beds (the first 3-4 weeks) were omitted from the relationships with temperature (in Figs. 4, 9 and 10). This coefficient $\mathrm{k}$ appears to be more strongly related to temperature in reed bed B (Fig. 4) than in reed bed A. In both cases the linear relationships are statistically highly significant, as indicated by coefficient of determination $R^{2}$ and the p-value in Fig. 4.

Some forms of nitrogen were removed efficiently by the reed beds. For the wastewater after mechanical treatment in reed bed $\mathrm{B}$, the input values of Kjeldahl nitrogen concentrations varied from $36.4 \mathrm{mg} \mathrm{dm}^{-3}$ to $101.4 \mathrm{mg} \mathrm{dm}^{-3}$. The efficiency of Kjeldahl nitrogen removal was between 45.2 and $91.8 \%$, but after the spring of 1997, after about one year of operation of the reed bed, the efficiency of nitrogen removal was largely stable at about $76.7 \%$ for the rest of the period of the experiment (for the next year). 
KALMAR ECO-TECH'01

Leachate and Wastewater Treatment with High-Tech and Natural systems

KALMAR, SWEDEN, November 26-28, 2001

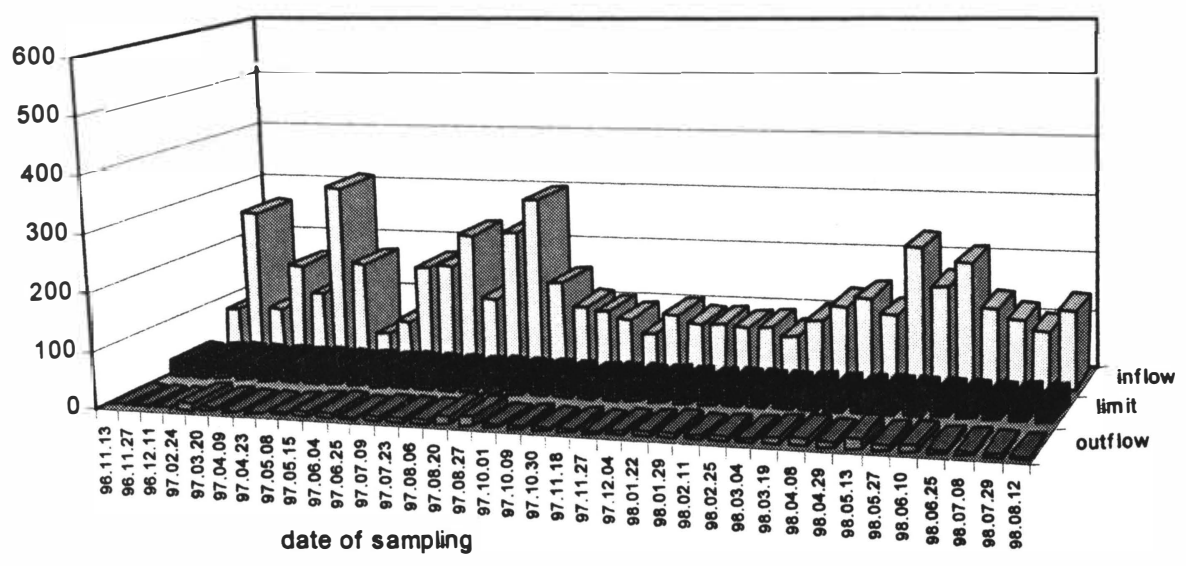

Figure 2. BODs $\left[\mathrm{mg} \mathrm{dm}^{-3}\right]$ in inflow and outflow wastewater, reed bed $A$

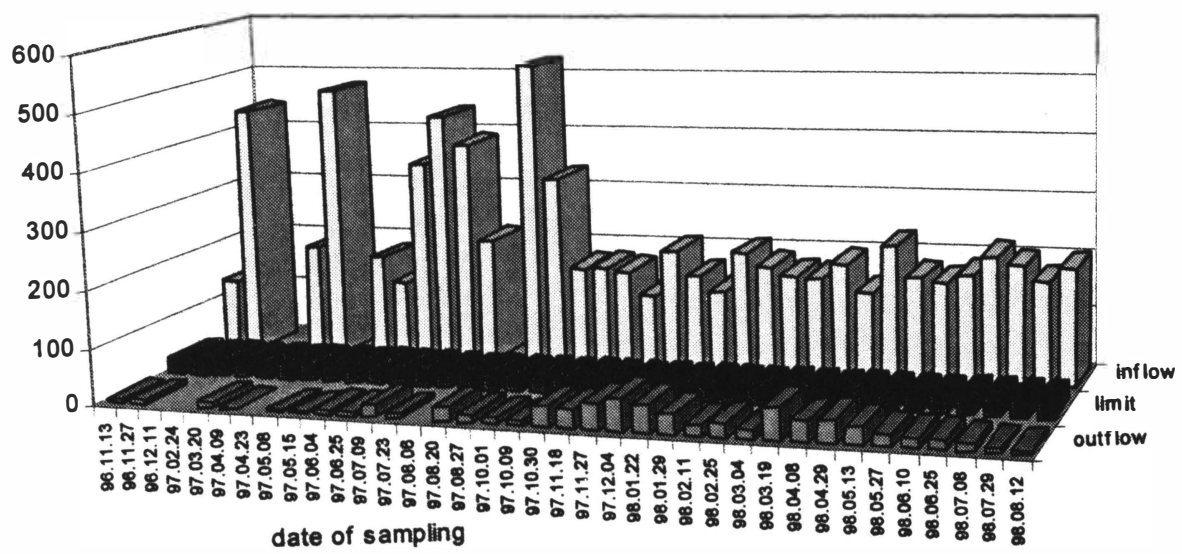

Figure 3. $B O D_{5}\left[\mathrm{mg} \mathrm{dm}^{-3}\right]$ in inflow and outflow wastewater, reed-bed $B$ 


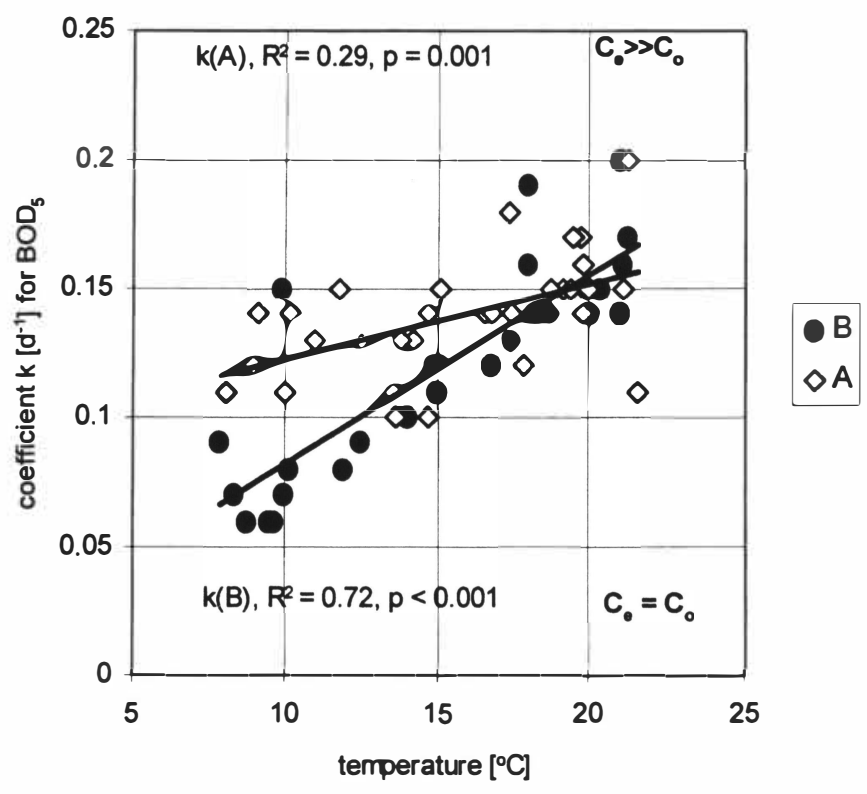

Fiure 4. Coefficient $k\left[d^{-1}\right]$ for $B O D_{5}$ removal in vertical reed-beds

Similarly for reed bed A, where the wastewater was irrigated after mechanical and biological treatment, input values of Kjeldahl nitrogen ranged from 30.8 to $63.8 \mathrm{mg} \mathrm{dm}^{-3}$. The efficiency of removal ranged from 14.5 to $97.4 \%$ and again after April 1997 was very stable during the next year at a mean level of $92.7 \%$.

Ammonia nitrogen in reed bed B was removed with a high degree of efficiency. Inputs ranged from $29.4 \mathrm{mg} \mathrm{dm}^{-3}$ to $78.2 \mathrm{mg} \mathrm{dm}^{-3}$, but after April 1997 about $79.1 \%$ of this pollutant was eliminated, even with relatively high concentrations in the irrigated wastewater. In reed bed A the situation was similar, but the efficiency of removal of the ammonia nitrogen was higher than in reed bed B. After April 1997 the mean efficiency of removal was about 95.4\%, despite input values ranging from 14.1 to $36.2 \mathrm{mg} \mathrm{dm}^{-3}$ (Figs. 5 and 6). 
KALMAR ECO-TECH'01

Leachate and Wastewater Treatment with High-Tech and Natural systems

KALMAR, SWEDEN, November 26-28, 2001

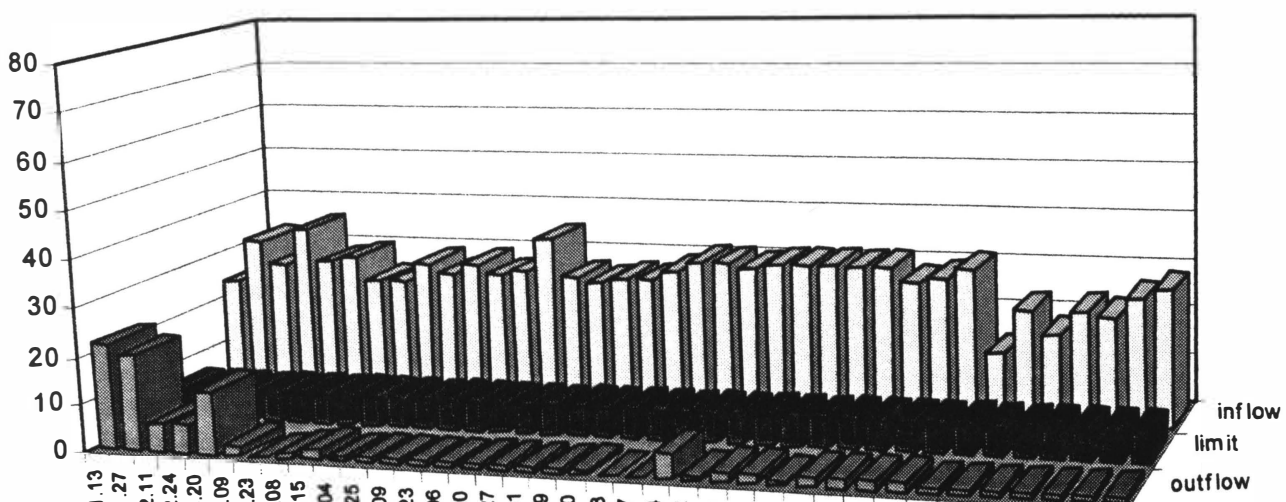

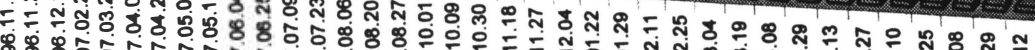

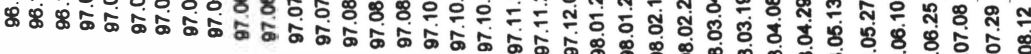
date of sampling

Figure 5. Ammonia nitrogen [ $\mathrm{mg} \mathrm{dm^{-3 }}$ ] in inflow and outflow wastewater, reed-bed $A$

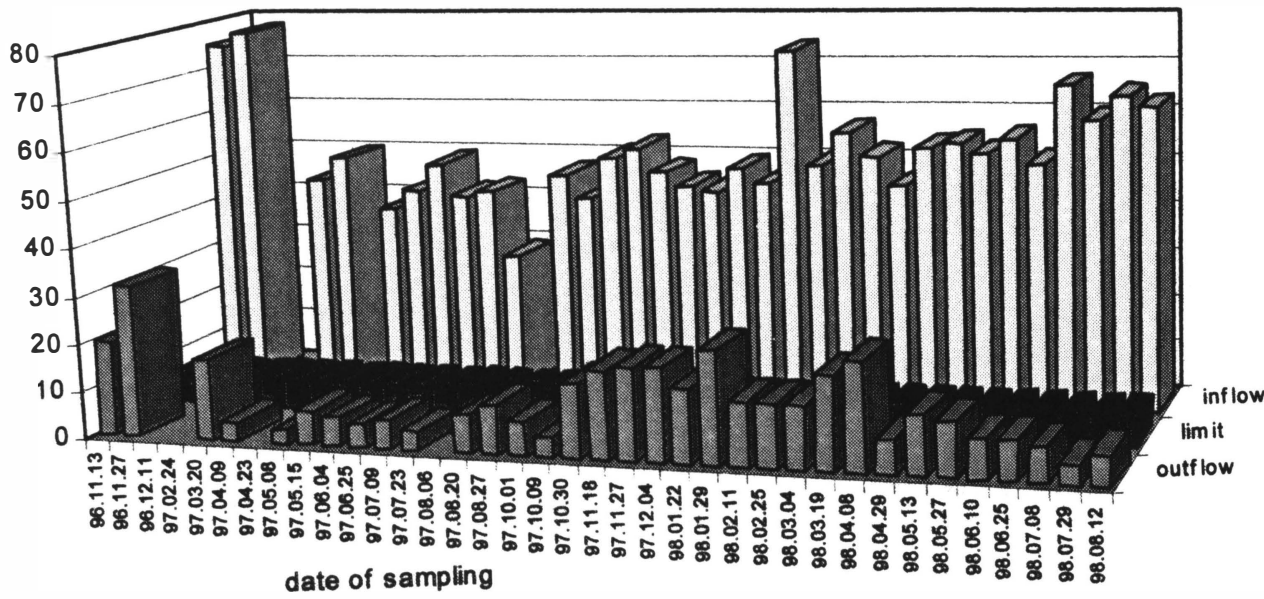

Figure 6. Ammonia nitrogen [ $\mathrm{mg} \mathrm{dm^{-3 }}$ ] in inflow and outflow wastewater, reed-bed $B$ 
Organic nitrogen elimination was measured only after one year of operation of the system. The efficiency during the second year was about $70 \%$ in reed bed $\mathrm{B}$ with input values of organic nitrogen from 7.0 to $52.6 \mathrm{mg} \mathrm{dm}^{-3}$. In reed bed A efficiency was observed to be stable from July 1997 (after one and a half-year's operation), at a level of $89.5 \%$ despite great fluctuations in the input, from 1.3 to $34.0 \mathrm{mg} \mathrm{dm}^{-3}$ of organic nitrogen.

Total nitrogen concentrations (the sum of Kjeldahl, nitrite and nitrate nitrogen), are shown in Figs. 7 and 8.

Removal of total nitrogen was not very efficient. Total nitrogen was assumed to be eliminated by plant uptake and denitrification, but these processes need more research in the future. Both ammonia and organic nitrogen removal is efficient, whereas total nitrogen removal is not. This is due to conversion in the bed of ammonia and organic $\mathrm{N}$ to nitrate. Consequently, denitrification losses and plant uptake would appear to be small, perhaps due to the aerobic environment of VF beds allowing oxidation but not also denitrification.

Total phosphorus was eliminated only to a limited extent. All forms of phosphorus (total phosphorus and orthophosphates), were similar in input and in output wastewaters. In some periods the concentrations in outputs were higher than in inputs, indicating the small retention and easy outflow of phosphorus from gravel beds. The mean efficiency of total phosphorus removal from wastewater after mechanical treatment in reed bed $B$ was about $17.8 \%$. In reed bed $\mathrm{A}$ irrigated by wastewater after mechanical and biological treatment the efficiency of removal of total phosphorus was only $7.7 \%$. For orthophosphates $\left(\mathrm{PO}_{4}{ }^{3-}\right)$ the efficiency of removal was $10.7 \%$ in reed bed $B$ and $2.6 \%$ in reed bed $A$.

Under Polish environmental regulations permissible concentrations in treated wastewater outflows are: total suspended solids $<50 \mathrm{mg} \mathrm{dm}^{-3}$; $\mathrm{BOD}_{5}<50 \mathrm{mg} \mathrm{dm}^{-3}$; total nitrogen $<30$ $\mathrm{mg} \mathrm{dm}{ }^{-3}$; ammonia nitrogen $<6 \mathrm{mg} \mathrm{dm}^{-3}$; total phosphorus $<5 \mathrm{mg} \mathrm{dm}^{-3}$. In most cases these requirements were met, with the exception of phosphorus and some total nitrogen samples.

Changes in wastewater pollution loads have been calculated from the product of pollution concentration and the inflow volumes and used to compare the removal performance of reed beds (see Appendix; Eqn. 18). 


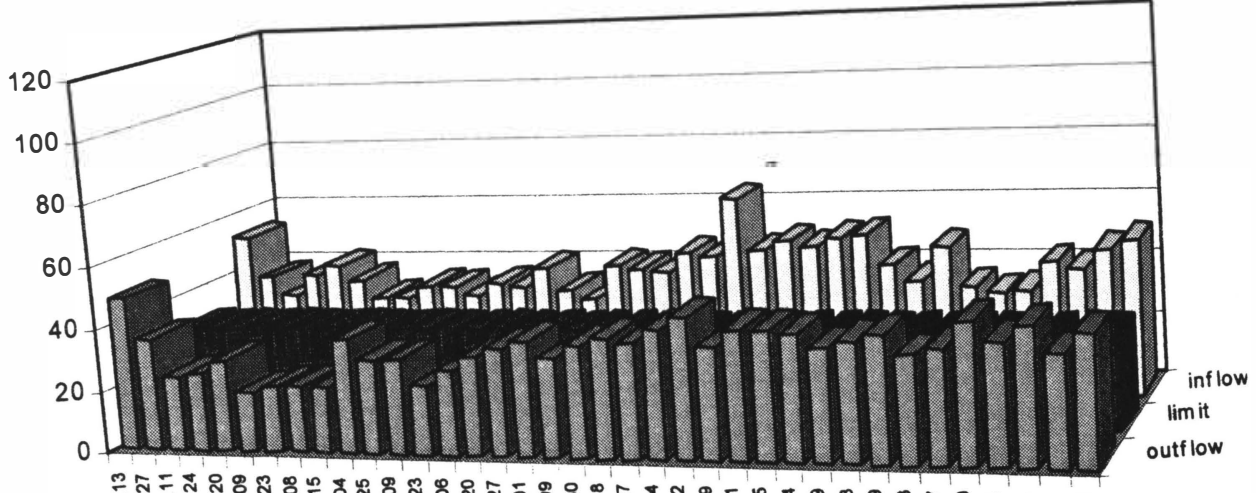

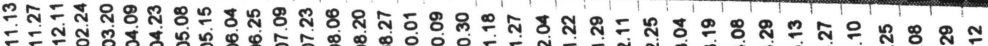

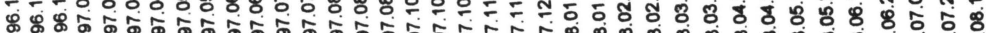
date of sampling

Figure 7. Total nitrogen [ $\mathrm{mg} \mathrm{dm}$ ] in inflow and outflow wastewater, reed-bed $A$

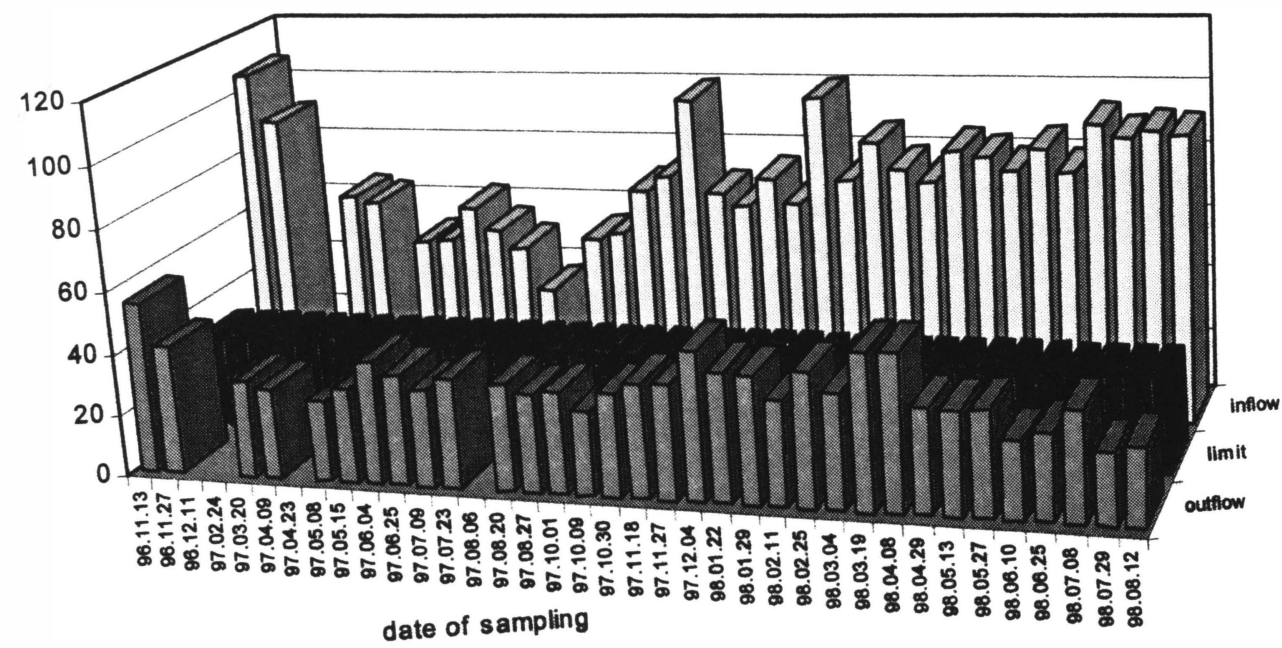

Figure 8. Total nitrogen in inflow and outflow wastewater, reed-beds $B$ 
KALMAR ECO-TECH'01

Leachate and Wastewater Treatment with High-Tech and Natural systems

KALMAR, SWEDEN, November 26-28, 2001

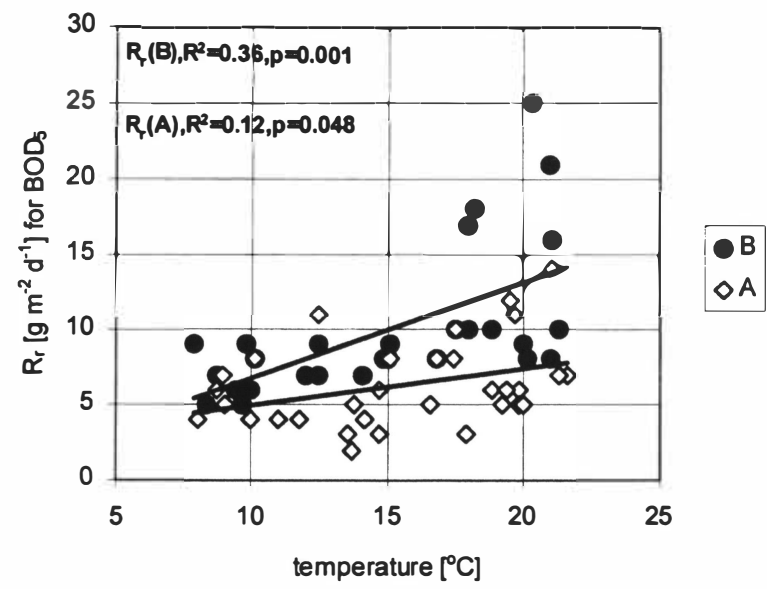

Figure 9. Rate of pollution removal $R_{r}\left[\mathrm{~g} \mathrm{~m}^{-2} d^{-1}\right]$ for $B O D_{5}$

The rate of removal of $\mathrm{BOD}_{5}$ and of total nitrogen expressed on a daily basis and per unit area of reed bed $\left(\mathrm{g} \mathrm{m}^{-2} \mathrm{~d}^{-1}\right)$, were compared with respect to the measured temperatures of the reed beds (Figs. 9-10).

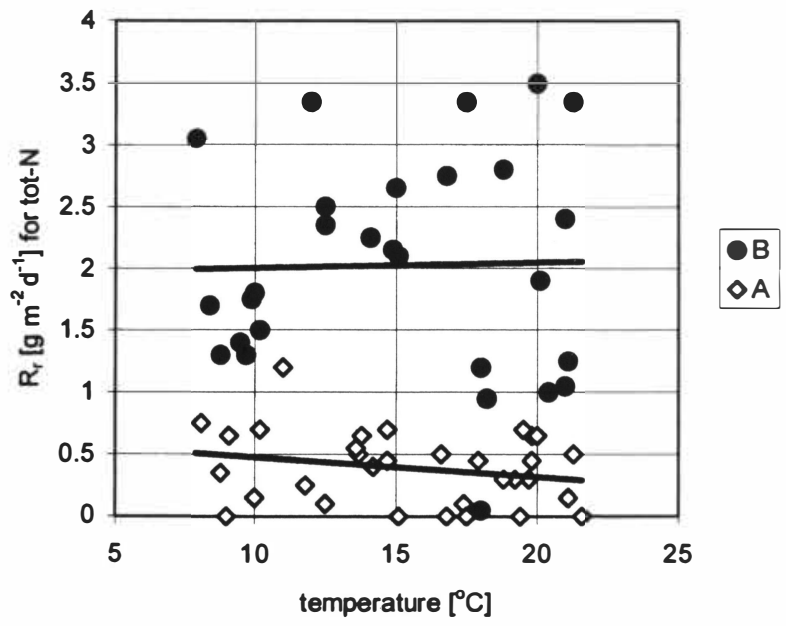

Figure 10. Rate of pollution removal $R_{r}\left[\mathrm{~g} \mathrm{~m}^{-2} d^{-1}\right]$ for total nitrogen,t for $R_{r}(B)$, $R^{2}=0.0005, p=0.909 ;$ for $R_{r}(A), R^{2}=0.051, p=0.214$ 
The rate of removal of $\mathrm{BOD}_{5}$ was higher for higher temperatures, the linear regression relationship being highly significant for reed bed B, but only marginally so far for A (Fig. 9). In winter the wastewater temperatures were never below 8-10aC (even during frosty days) and in summer were in the range 20-22aC. At higher temperatures, reed bed B (wastewater after mechanical treatment) was eliminating almost two times more $\mathrm{BOD}_{5}$ than reed bed $\mathrm{A}$ (wastewater after mechanical and biological treatment) and the removal rates were much more variable than in winter (Fig. 9).

In the case of total nitrogen removal, in neither bed A nor B was there any apparent relationship with temperature (Fig. 10). The strongest temperature effect could be seen with $\mathrm{k}\left(\mathrm{BOD}_{5}\right)$ in reed bed $\mathrm{B}$ (Fig. 4).

\section{CONCLUSIONS}

Both reed beds show high efficiency at eliminating suspended solids, $\mathrm{BOD}_{5}$, organic and ammonia nitrogen.

Elimination of nitrogen pollution stabilised after one year of operation of the reed beds.

The rate of removal of $\mathrm{BOD}_{5}$ varied between 5 and $25 \mathrm{~g} \mathrm{~m}^{-2} \mathrm{~d}^{-1}$ for wastewater after mechanical treatment (bed B); and between 2 and $15 \mathrm{~g} \mathrm{~m}^{-2} \mathrm{~d}^{-1}$ for wastewater after mechanical and biological treatment (bed A).

The rate of removal of total nitrogen varied between 0.05 and $3.5 \mathrm{~g} \mathrm{~m}^{-2} \mathrm{~d}^{-1}$ for wastewater after mechanical treatment (bed B); and between 0 and $1.2 \mathrm{~g} \mathrm{~m}^{-2} \mathrm{~d}^{-1}$ for wastewater after mechanical and biological treatment (bed A).

The removal rate for $\mathrm{BOD}_{5}$ was about twice as big in reed bed $\mathrm{B}$ as in $\mathrm{A}$, whereas for total $\mathrm{N}$ it was about 4 times as big.

Rates of $\mathrm{BOD}_{5}$ removal varied 3-fold with temperature in reed bed $\mathrm{B}\left(5 \mathrm{~g} \mathrm{~m}^{-2} \mathrm{~d}^{-1}\right.$ at $8 \mathrm{aC}$ and $15 \mathrm{~g} \mathrm{~m}^{-2} \mathrm{~d}^{-1}$ at $22 \mathrm{aC}$ ), but less so in reed bed $\mathrm{A}$ (rates 4 and 7 respectively).

This difference between summer and winter indicates that the surface area of constructed wetland $\mathrm{B}$ should be about 3 times bigger during winter to obtain the summer rate of $\mathrm{BOD}_{5}$ pollution removal in the climatic conditions of North Poland ( $54 a \mathrm{~N})$.

The vertical flow reed bed was not efficient for removal of phosphorus.

Process modelling of constructed wetlands is established to a point where mathematical relationships are now available for estimating a system's ability to remove major pollutants (see Appendix).

\section{ACKNOWLEDGEMENTS}

This research was supported by a grant of Polish Committee on Research and Development (KBN), no. 084/P04/95/08 and by School of Biosciences, Cardiff University, U.K., "Salix Project". Great appreciation is given to the SAUR NEPTUN GDANSK Co. for the kind offer of the terrain, installations and buildings at the WWTP ZASPA Gdansk, making the field research possible.

\section{APPENDIX. Equations describing the purification process within a vertical flow wetland system}


Design parameters for constructed wetland systems include: hydraulic retention time, basin depth, basin geometry (width and length) and hydraulic loading rate. For a reed bed solution designed to achieve suspended solids, $\mathrm{COD}, \mathrm{BOD}_{5}$ and nitrogen removal, the required retention time may be estimated, using first-order plug-flow kinetics, assuming a uniform mass flow from surface to base of the bed. Taking symbols:

$n$ - water filled porosity of the sand-bed or gravel-bed, occupied by capillary water with biofilm after drainage of freely outflowing water, here about $0.10[-]$;

$W$ - basin width, here perpendicular to the direction of flow [m];

$L$ - basin length, here perpendicular to the direction of flow[m];

$A$ - surface area of the reed bed, $W^{*} L\left[\mathrm{~m}^{2}\right]$;

$H$ - basin depth, here parallel to the flow [m];

$x$ - the distance of flow of wastewater measured in the direction of flow, from 0 to $H$ in vertical flow bed, but from 0 to $L$ in horizontal flow bed $[\mathrm{m}]$;

$C$ - concentration of $\mathrm{BOD}_{5}$ or nitrogen forms during the flow of waste water in the reed bed $\left[\mathrm{mg} \mathrm{dm}^{-3}\right]=\left[\mathrm{g} \mathrm{m}^{-3}\right]$;

$C_{o}$ - initial pollutant concentration (inlet) $\left[\mathrm{mg} \mathrm{dm}^{-3}\right]=\left[\mathrm{g} \mathrm{m}^{-3}\right]$;

$C_{x}$ - pollutant concentration at some distance $\mathrm{x}$ during the flow $\left[\mathrm{mg} \mathrm{dm}^{-3}\right]=\left[\mathrm{g} \mathrm{m}^{-3}\right]$;

$C_{e}$ - final pollutant concentration (outlet, end) $\left[\mathrm{mg} \mathrm{dm}^{-3}\right]=\left[\mathrm{g} \mathrm{m}^{-3}\right]$;

$C \mathrm{t}$ - limit, permissible pollutant concentration in outlet $\left[\mathrm{mg} \mathrm{dm}^{-3}\right]=\left[\mathrm{g} \mathrm{m}^{-3}\right]$;

$Q-$ mean average flow rate per day of wastewater through system $\left[\mathrm{m}^{3} \mathrm{~d}^{-1}\right]$;

$R$ - pollution loading rate indicating the amount of pollution per square meter of reed bed per day $\left[\mathrm{g} \mathrm{m}^{-2} \mathrm{~d}^{-1}\right]$;

$R_{r} \mathrm{e}$ - rate of pollution removal by reed bed $\left[\mathrm{g} \mathrm{m}^{-2} \mathrm{~d}^{-1}\right]$;

$T$ - temperature of wastewater in reed bed $\left[{ }^{\circ} \mathrm{C}\right]$;

$V$ - active volume of biofilm of the reed bed $\left[\mathrm{m}^{3}\right]$;

$V_{x}$ - the active volume at the distance $\mathrm{x}$ from the beginning of flow $\left[\mathrm{m}^{3}\right]$;

$t$ - real time [d];

$t_{r}$ - average retention time of wastewater in the reed bed [d];

$t_{r x}$ - average retention time of wastewater related to the distance $x$, in [d];

$k$ - temperature-dependent first-order kinetics constant $\left[\mathrm{d}^{-1}\right]$;

$k\left(20^{\circ} \mathrm{C}\right) \mathrm{t}-$ first-order kinetics constant for temperature $20^{\circ} \mathrm{C}\left[\mathrm{d}^{-1}\right]$;

$K=k^{*} n^{*} H$, additional coefficient of kinetics [ $\left.\mathrm{m} \mathrm{d}^{-1}\right]$;

ln - natural logarithm.

The pore-space retention time $t_{r}$ is determined as a function of the active volume of the reed bed $V$ and the flow rate $Q$ :

$t_{r}=V / Q$

In a vertical flow bed the input is not a continous flow, as in a horizontal flow bed. Here there is rapid drainage after the pulse of wastewater, followed by an unsaturated phase. $Q$ is a mean daily value and the wastewater is in contact with the bed for a shorter time than if the flow were constant, however it may still be treated as a plug flow reactor, even if the flow is in small pulses, as the flow Q, is averaged over time.

The active volume of the reed bed may be calculated from the equation:

$V=n * W^{*} L * H$

But, at a given distance $x[\mathrm{~m}]$ from the point of entering the reed bed surface:

$V_{x}=n * W * L * x$

and the retention time for the treatment process at distance $x$ is based on the active porosity of the medium: 
Constructed wetland systems can be considered as large-scale attached growth fixed film biological reactors and their performance can be described with first-order plug-flow kinetics. A steady-flow first-order irreversible reaction in a plug flow reactor is described as:

$d C / d t \mathrm{e}^{-}-k^{*} C$

This is analogous to the well-known equation in population dynamics, describing population $C$ over time, where $k$ may be understood as a "death rate coefficient" of the population. Writing:

$d C / C \mathrm{e}=-k^{*} d t$

$\int d C / C=-\int k d t$

Real time $t$ may be substituted here by the $t_{r x}$, the hydraulic retention time of the reactor, taken as the so-called pore-space retention time of the reed bed medium at the distance of flow $x$. The boundary conditions of integration are:

for $x=0, C=C_{o}, t_{r x}=0$;

for $x=x, C=C_{x}, t_{r x}=t_{r x}$;

for $x=H, C=C_{e}, t_{r x}=t_{r}$ and:

$\int_{C_{0}}^{C_{x}} d C / C=-\int_{0}^{t_{r x}} k d t$

$\ln \left(C_{x} / C_{\alpha}\right) \mathrm{e}=-k * t_{r x}$

The forward (predictive) solution of the input-output relation has the shape:

$C_{x}=C_{o} * \exp \left(-k * t_{r x}\right)$

And taking the distance $x=H$ at the end of the flow in the reed bed (output):

$C_{e}=C_{o} * \exp \left(-k^{*} t_{r}\right)$

This equation (1t) was presented in the EPA Design Manual (1988), but a kinetic degradation model had been previously used for $\mathrm{BOD}_{5}$ elimination by Kickuth (1981). The inverse solution for the first-order kinetic constant $k$ (for estimation of the value of $k$, having measured $C_{o} C_{e}$ and $\left.t_{r}\right)$ is:

$k=-\ln \left(C_{e} / C_{o}\right) / t_{r}$

and having input concentration, output concentration and hydraulic retention time of an existing reed bed, one may establish the magnitude of the $k$ value. The value of $\mathrm{k}$ is here specific to the VF system because of the pulses supply of wastewater, and differs from $k$ for horizontal flow system. The tranformations are:

$t_{r} \mathrm{e}=-\ln \left(C_{e} / C_{o}\right) / k$

$\left(n * H^{*} A\right) / Q \mathrm{e}=\left(\ln C_{o}-\ln C_{e}\right) / k$

$A=\left\{Q *\left(\ln C_{o}-\ln C_{e}\right)\right\} /(k * n * H)$

$A=Q^{*}\left(\ln C_{o}-\ln C_{e}\right) / K$

The last equation is used by EPA Design Manual (1988) and by Cooper et al. (1996). It is important to note the difference between $k$ and $K$ in given equations (where $K=k^{*} n^{*} H$ ). The value of $C_{e}$ in the last equation may be the permissible level of the outflow concentration required by regulatory authorities as part of discharge licenses $\left(C_{l}>C_{e}\right)$ (Bastian et al., 1989) and in this case the value of $A$ may be the surface area needed for efficient wastewater treatment by the constructed wetland. The pollution loading rate $R$ is calculated:

$R=Q * C_{o} / A$

and the rate of removal of the pollution is:

$R_{r}=Q^{*}\left(C_{o}-C_{e}\right) / A$ 
Values of $R_{r}$ and $k$ may be dependent upon temperature of the sewage in the reed bed $T\left[{ }^{\circ} \mathrm{C}\right]$ by well-known Arrhenius equation:

$k=k\left(20^{\circ} \mathrm{C}\right) *(1 \mathrm{e} 06)^{(\mathrm{T}-20)}$

using 1.06 here instead of 1.10 . The relation $\mathrm{k}(\mathrm{T})$ may be approximated by a linear model as well, taking $k(T)=a * T+b$, where $a$ and $b$ are empirical parameters. If the temperature of wastewater is between 15 and $20^{\circ} \mathrm{C}$ the Equation (19) need not be used. The efficiency of pollution removal is defined as:

$\eta \in=\left\{\left(C_{0}-C_{e}\right) / C_{0}\right\} * 100 \quad[\%]$

\section{REFERENCES}

1. Bastian, R.K., Shanagan, P.E., Thompson, B.P., 1989. Use of wetlands for municipal waste water treatment and disposal - regulatory issues and EPA policies. In: D.A. Hammer (Ed.) Constructed wetlands for waste water treatment, municipal, industrial and agricultural. Lewis Publishers, Chelsea, Michigan, 265-278.

2. Belfiore, N.A., 1997. A pilot study of a vertical flow constructed wetland at 'ZASPA', Gdansk, Poland. MSc Thesis, Supervisor Dr P.F. Randerson, Department of Pure and Applied Biology, Universdity of Cardiff, Wales, U.K., pp. 117.

3. Brix, H., 1987. Treatment of wastewater in the rhizosphere of wetland plants - the root-zone method. Wat. Sci. Tech., 19, 107-119.

4. Brix, H., 1993. Wastewater treatment in constructed wetlands: system design, removal processes and treatment performance. In: G.A. Moshiri (Ed.) Constructed Wetlands for Water Quality Improvement. CRC Press, Boca Raton, 9-22.

5. Cooper, P.F., Job, G.D., Green, M.B., Shutes, R.B.E., 1996. Reed beds and constructed wetlands for wastewater treatment. WRc Swindon, U.K., pp. 184.

6. EPA Design Manual, 1988. Constructed wetlands and aquatic plant systems for municipal waste water treament: design manual. US EPA Publication 625/1-88/022, Centre for Environmental Research Information, Cincinnati, OH 45268, pp. 83.

7. Felde, K., Kunst, S., 1996. $\mathrm{N}$ and COD removal in vertical flow systems. In: Proceedings of the $5^{\text {th }}$ International Conference on Wetland Systems for Water Pollution Control. Vienna, I/8-1 - I/8-8.

8. Heritage, A., Pistillo, P., Sharma, K.P., Lantzke, I.R., 1995. Treatment of primarysettled urban sewage in pilot-scale vertical flow wetland filters: comparison of four emergent macrophyte species over a 12 month period. Wat. Sci. Tech., 32(3), 295-304.

9. Hiley, P.D., 1995. The reality of sewage treatment using wetlands. Wat. Sci. Tech., 32(3), 329-338.

10. Kickuth, R., 1981. Abwasserreinigung in Mosaikmatrizen aus anaeroben und aeroben Teilbezierken. Grundlangen der Abwasserreiningung. GWF Schriftreihe WasserAbwasser, 19, Oldenburg Verlag, Oldenburg.

11. Kowalik P.J., Obarska-Pempkowiak H., 1985. Determination of the permissible amount of liquid animal waste applied to soil filters. Agricultural Water Management, 10:313-326. 
12. Kowalik, P.J., Randerson P.F., 1995. Nitrogen and phosphorus removal by willow stands irrigated with municipal wastewater - a review of Polish experience. Biomass and Bioenergy, 6(1/2), 133-139.

13. Kowalik P.J., Barnes C.J., Smiles D.E., 1979. Oxidation of liquid animal wastes in soil. Soil Science Society of America Journal, 43(2):255-260.

14. Kowalik, P.J., Mierzejewski, M., Obarska-Pempkowiak, H., Toczylowska, I., 1995. Constructed wetlands for wastewater treatment of small communities. Center of Environmental Studies, CENVIG, Polytechnical University of Gdansk, pp. 70.

15. Kowalik, P.J., Slater, F.M., Randerson, P.F., 1996. Constructed wetlands for landfill leachate treatment. In: L. Thofelt and A. Englund (Eds.) Ecotechnics for a Sustainable Society, Oestersund, Chapter 16, pp. 12.

16. Mitchell, D.S., Chick, A.J., Raisin, G.W., 1995. The use of wetlands for water pollution control in Australia: an ecological perspective. Wat. Sci. Tech., 32(3), 365-373.

17. Mierzejewski, M., 1999. Efficiency of the elimination of nutrients on the reed beds with vertical flow. PhD Thesis. Politechnical University of Gdansk, Poland, 165 pp. (in Polish). 